Vol. 3, No. 2, Juli 2019, 91-99

Available Online at https://ejournal.warmadewa.ac.id/index.php/kulturistik DOI: dx.doi.org/10.22225/kulturistik.3.2.1221

\title{
JARGON CAPRES - CAWAPRES FIKTIF; NURHADI - ALDO DALAM WACANA PRA-PEMILU DI INDONESIA TAHUN 2019
}

\author{
I Gede Dwi Setiadi \\ STISIP Margarana Tabanan \\ igededwisetiadi@stisip-margarana.ac.id
}

\begin{abstract}
ABSTRAK
Penelitian ini membahas tetang fenomena kemunculan pasangan Capres-Cawapres fiktif Nurhadi-Aldo di tengah-tengah panasnya situasi perpolitikan Indonesia pra-Pemilu 2019 dengan sejumlah jargon-jargon yang unik. Keunikan jargon-jargon adalah hasil dari permainan kata-kata yang digunakannya sehingga menarik untuk dibahas secara makna dan struktur kalimatnya. Penelitian ini mengunakan sebuah teori yaitu teori analisis wacana untuk menemukan makna dari jargon-jargon tersebut. Teori analisis wacana terdiri dari tiga buah struktur yaitu (1) struktur makro, (2) superstruktur, dan (3) struktur mikro. Struktur makro terdiri dari ranah pengamatan tematik atau tema. Superstruktur terdiri dari ranah pengamatan skematik yaitu bagaimana struktur dan elemen wacana itu disusun dalam teks secara utuh. Struktur mikro terdiri dar ranah pengamatan (a) semantik, (b) sintaksis, (c) stilistika, dan (d) retoris. Tetapi, dalam penelitian ini ranah pengamatan sintaksis tidak digunakan karena dianggap tidak ada data yang dapat diteliti.
\end{abstract}

Kata kunci: jargon, capres-cawapres, nurhadi-aldo, pemilu 2019

\begin{abstract}
[Title: The Jargon of Presidential and Vice Presidential Candidate; Nurhadi-Aldo in the Pre-Election Discourse in Indonesia in 2019] This study discusses the phenomenon of the emergence of the fictional vice-presidential candidate Nurhadi-Aldo in the midst of the heat of the situation in 2019 pre-election Indonesian politics with a number of unique jargon. The uniqueness of jargon is the result of the words that are used so it is interesting to discuss the meaning and structure of the sentence. This study uses a theory that is discourse analysis theory to find the meaning of these jargon. The theory of discourse analysis consists of three structures, namely (1) macro structure, (2) superstructure, and (3) microstructure. The macro structure consists of thematic observation domains or themes. The superstructure consists of a schematic field of observation, namely how the structure and elements of the discourse are arranged in full text. The micro structure consists of the domains of observation (a) semantics, (b) syntax, (c) stylistics, and (d) rhetorical. However, in this study the realm of syntactic observation is not used because it is considered that no data can be examined.
\end{abstract}

Keywords: jargon, vice-presidential candidate, nurhadi-aldo, election 2019

\section{PENDAHULUAN}

Suasana pra-Pemilu di tahun 2019 yang 'panas' menimbulkan berbagai konflik di tengah-tengah masyarakat dari berbagai golongan, mulai dari golongan elit hingga masyarakat awam. Bahkan, pemuka agama juga ikut kehilangan netralitas mereka karena larut dalam suasana politik. Perpecahan pun tak dapat 
Vol. 3, No. 2, Juli 2019, 92

Available Online at https://ejournal.warmadewa.ac.id/index.php/kulturistik DOI: dx.doi.org/10.22225/kulturistik.3.2.1221

dihindari akibat perbedaan ini. Hampir di setiap media masa baik cetak maupun online dipenuhi dengan perdebatan dan hinaan dari masing-masing tim sukses maupun simpatisan pasangan calon presiden dan wakil presiden kedua kubu. Istilah seperti 'cebong' dan 'kampret' dimunculkan sebagai hinaan bagi masingmasing pendukung pasangan calon. Tidak hanya itu, fitnah berupa berita bohong (hoax) kerap kali digunakan untuk menyerang kedua pasangan calon presiden dan wakil presiden dengan tujuan merusak citra salah satu pasangan. Maka masyarakat yang tidak begitu paham politik menjadi ikut-ikutan untuk menjadi anarkis dan melontarkan kalimat-kalimat sarkas untuk mengekspresikan kemarahannya.

Di tengah suasana tersebut tanpa diduga muncul dua tokoh yang menjadi 'pendingin' suhu politik yaitu Nurhadi dan Aldo dengan identitas mereka sebagai pasangan presiden dan wakil presiden fiktif yang tergabung dalam koalisi Indonesia Tronjal-Tronjol Maha Asyik. Pasangan Nurhadi-Aldo atau yang disingkat DILDO ini memberikan nuansa baru dalam perpolitikan Indonesia yang semakin liar. Mereka sering muncul di sosial media dengan gambar diri mereka dan jargon -jargon lucu khas DILDO misalnya seperti jargon "Kalau mereka bisa, kenapa harus kita?". Tidak jarang mereka membuat jargon yang bersifat dewasa dan tidak ada hubungannya samasekali dengan poitik. Namun di balik itu semua, jargonjargon milik Capres-Cawapres fiktif ini cukup berhasil menstabilkan kondisi politik di Indonesia untuk sementara.

Jargon berarti kosakata khusus yang digunakan dalam ranah tertentu ("Kamus Besar Bahasa Indonesia," n.d.). Jargon adalah suatu kosakata yang khas yang dipakai dalam bidang kehidupan tertentu, seperti sering ditemukan dalam suatu komunitas tertentu seperti komunitas para sopir truk yang tidak dipakai ataupun jarang dipahami oleh orang dari bidang lain (Kridalaksana, 2008). Dalam Tesaurus Bahasa Indonesia, jargon disebut juga patois, slang, atau slogan (Endarmoko, 2006).

Jargon di dalam ranah politik seringkali memang sengaja diciptakan dan kemudian disebarkan sebagai instrumen kepentingan pihak tertentu. Berbagai jargon digunakan oleh para elit politik untuk menampilkan citra yang positif dirinya maupun golongannya, contohnya di masa kepemimpinan Presiden RI ke-6 Susilo Bambang Yudhoyono yang memiliki jargon yaitu "Katakan tidak untuk korupsi.". Jargon tersebut diciptakan untuk mencitrakan pemerintahan yang sehat dan bersih dari korupsi. Di sisi lain, Presiden RI ke-7 sekaligus calon Presiden tahun 2019 Joko Widodo selalu mengusung jargon "Kerja kerja kerja." juga sebagai wajah positif kepemimpinannya sealigus menjadi sindiran bagi pemerintahan sebelumnya yang dianggap tidak bekerja secara maksimal bagi rakyat.

Secara sederhana wacana memiliki pengertian suatu ide atau gagasan tertentu yang oleh pembicara atau penulis disampaikan kepada para pendengar ataupun pembaca dengan mengunakan media bahasa. Pada ranah linguistik, wacana digunakan untuk menggambarkan sebuah struktur yang lebih luas melebihi batasan kalimat. Wacana adalah satuan bahasa yang lengkap, sehingga dalam hirarki gramatikal merupakan satuan gramatikal tertinggi atau terbesar. Sebagai satuan bahasa yang lengkap, maka dalam wacana juga berarti terdapat konsep, gagasan, pikiran, bahkan ideologi yang utuh dan dapat dipahami pembaca maupun pendengar(Chaer, 2011)."

Penelitian ini berusaha mengupas secara lugas penggunaan bahasa yang ditampilkan oleh pasangan Nurhadi-Aldo dalam fenomena politik di Indonesia pra-Pemilu tahun 2019. Beberapa hal yang menjadi dasar penulis untuk 
Vol. 3, No. 2, Juli 2019, 93

Available Online at https://ejournal.warmadewa.ac.id/index.php/kulturistik DOI: dx.doi.org/10.22225/kulturistik.3.2.1221

mengangkat judul ini ialah karena: (1) adanya kekhasan bahasa yang digunakan oleh pasangan Nurhadi-Aldo ini, (2) keintensifan dalam membuat jargon-jargon baru dan segar, (3) momentum yang sangat tepat dari kemunculan pasangan ini guna meredam suhu politik di tengah masyarakat. Ketiga faktor tersebut menjadi alasan mengapa jargon-jargon Nurhadi-Aldo dijadikan sebagai bahan penelitian sederhana ini.

Dalam proses analisis teks terdapat tiga buah tingkatan, yaitu: (1) struktur makro yang merupakan makna umum dari sebuah teks yang dipahami dengan melihat topik yang dibicarakan pada teks tersebut atau disebut juga ranah pengamatan tematik. Tematik adalah tema, yaitu pesan utama yang ingin diungkapkan oleh penulis melalui tulisannya (Gorys, 1980). Menurut Shipley dalam (Sayuti, 2000), jenis tema berdasarkan pokok pembicaraanya terdiri dari lima jenis, yaitu: (a) tema jasmani (physical), yang berbicara tentang manusia secara jasmani, (b) tema organik (moral), adalah tema yang berhubungan dengan moral manusia, (c) tema sosial, adalah tema tentang aspek sosial manusia, (d) tema egoik, adalah tema mengenai respon personal manusia sebagai individu mengenai hak-hak mereka, dan (e) tema ketuhanan (divinity), adalah tema mengenai kondisi dan situasi manusia sebagai makhluk ciptaan Tuhan. (2) superstruktur, adalah kerangka sebuah teks yang menjadi struktur dan elemen-elemen pendukung wacana yang terdapat pada teks, ranah pengamatannya disebut sebagai skematik. Skema alur adalah bagaimana sebuah teks tersaji, bagaimana struktur dan berbagai elemen wacana disusun menjadi sebuah teks yang utuh dan menjadi rangkaian teks yang terdiri dari pembukaan, isi dan penutup. Van Dijk juga menyebutkan beberapa elemen skema lainnya, yaitu: (a) skema persona (person schemas): adalah cara seseorang dalam menilai maupun memandang orang lain, (b) skema diri (self schemas): skema ini berbicara tentang bagaimana diri sendiri dicitrakan dan dipahami oleh orang lain, (c) skema peran (role schemas): skema ini terkait cara seseorang memandang dan menggambarkan peranan atau fungsi seseorang dalam masyarakat, (d) skema peristiwa (event schemas): adalah skema yang berkaitan dengan bagaimana seseorang memahami suatu peristiwa. (3) struktur mikro, merupakan makna dari wacana yang terkandung dalam teks dengan cara menganalisis kata, kalimat, preposisi, anak kalimat, maupun parafrasanya. Ranah pengamatan dari struktur mikro adalah semantik, sintaksis, stilistika dan retoris. Secara umum semantik adalah ilmu bahasa yang mengkaji makna satuan lingual, baik leksikal maupun gramatikal sedangkan sintaksis berbicara tentang penataan bentuk dan susunan kalimat dalam terbangunnya suatu gagasan atau ide yang logis. Tiap-tiap unsur kalimat dijalin sedemikian rupa sehingga membentuk kesatuan yang selaras. Stilistika disebut juga dengan gaya bahasa (style), adalah cara yang digunakan penulis atau pembicara dalam menyampaikan maksudnya dengan gaya tertentu. Suatu gaya bahasa adalah berupa diksi/pilihan kata guna membentuk makna tertentu. Dengan pemilihan kata yang tepat, satu peristiwa yang sama dapat digambarkan dengan cara yang berbeda. Retoris adalah cara seorang pembicara atau penulis berinteraksi ketika mereka berbicara maupun menulis. Contohnya dengan menggunakan bahasa yang hiperbolik, atau bahkan berputar-putar. Retoris juga berfungsi sebagai persuasi atau ajakan dan berpengaruh kuat terhadap pesan yang ingin disampaikan.

\section{METODE}

Instrumen yang digunakan dalam penelitian ini diantaranya: surat kabar, 
Vol. 3, No. 2, Juli 2019, 94

Available Online at https://ejournal.warmadewa.ac.id/index.php/kulturistik DOI: dx.doi.org/10.22225/kulturistik.3.2.1221

jaringan internet, dan scanner. Penelitian ini lebih menekankan pada kegiatan mengumpulkan dan mendeskripsikan data kualitatif yang berupa kumpulan berita tentang capres-cawapres fiktif Nurhadi-Aldo. Oleh karena itu, penelitian ini juga disebut dengan penelitian deskriptif-kualitatif. Penelitian kualitatif yang menekankan pada makna, lebih memfokuskan pada data kualitas dengan analisis kualitatifnya. Sumber data pada penelitian ini diambil dari berbagai surat kabar cetak maupun digital. Kutipan dipilih berdasarkan menarik atau tidaknya kutipan tersebut secara subjektif.

Dalam mengumpulkan data digunakan metode duplikasi dan catat. Teknik duplikasi yang dimaksud adalah melakukan scanning ataupun tangkap layar (screen-shot) terhadap kutipan-kutipan yang dianggap memiliki jargon yang menarik. Sebuah penelitian akan menarik apabila temuan-temuan disajikan secara sistematis, sehingga dapat dengan mudah dipahami pembaca, untuk itu hasil temuan harus disajikan dengan bahasa yang baik dan lugas. Penelitian ini akan menyajikan hasil analisis data dengan metode formal dan informal berdasarkan konsep (Sudaryanto, 1993). Metode formal adalah metode yang digunakan untuk menyajikan hasil temuan dengan menggunakan tanda, lambang, gambar dan diagram. Dengan menggunakan tanda, lambang dan gambar analisis yang disajikan diharapkan lebih mudah dipahami. Metode informal adalah metode yang digunakan untuk menyajikan hasil temuan dengan menggunakan kata-kata ataupun kalimat. Metode ini dianggap paling sesuai dalam menjelaskan permasalahan kualitatif dengan lebih baik apabila dibandingkan dengan metode yang lain.

\section{PEMBAHASAN}

Suntingan Gambar 1

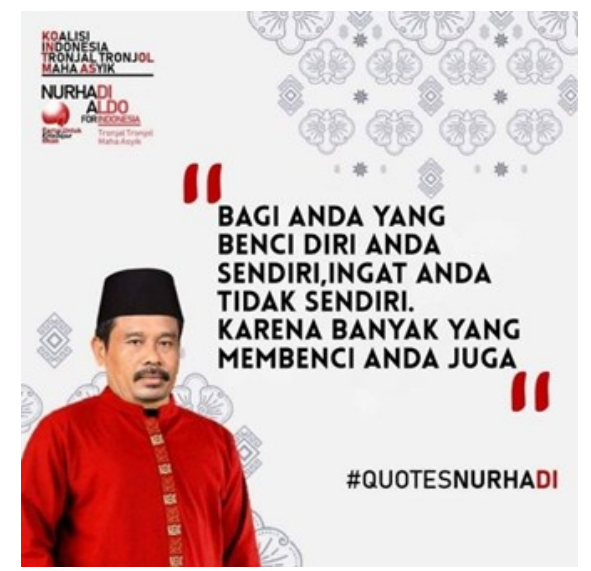

Gambar 1: gambar neologisme (meme) dengan jargon milik pasangan Capres-Cawapres fiktif Nurhadi-Aldo.

Suntingan Teks 1: "Bagi anda yang benci diri anda sendiri, ingat anda tidak sendiri, karena banyak yang membenci anda juga."

\section{Struktur Makro}

Struktur makro dalam ranah pengamatan tematik atau tema dari jargon di atas masuk pada dua hal yaitu: (1) tema sosial dan (2) tema egoik. Tema sosial 
Vol. 3, No. 2, Juli 2019, 95

Available Online at https://ejournal.warmadewa.ac.id/index.php/kulturistik DOI: dx.doi.org/10.22225/kulturistik.3.2.1221

ditujukkan dalam klausa 'diri anda sendiri', dan 'karena banyak yang membenci anda juga'. Hubungan sosial adalah hubungan antara pribadi dan orang lain, maka dari itu yang menjadi tema pokok dari jargon di atas adalah tema sosial. Tema minor atau tema tambahan jargon di atas adalah tema egoik. Pada klausa 'bagi anda yang benci diri anda sendiri', memiliki arti bahwa seseorang yang merasa benci terhadap dirinya sendiri, dimana perasaan tersebut merupakan bentuk ego diri yang menilai diri sendiri maupun orang lain.

\section{Superstruktur}

Superstruktur dalam ranah pengamatan skematik memasukkan jargon di atas ke dalam skema persona (person schemas). Hal tersebut karena jargon tersebut berisikan hal tentang pandangan seseorang terhadap orang lain. Orang lain yang dimaksud adalah orang yang membenci dirinya sendiri seperti yang tertulis pada jargon.

\section{Struktur Mikro}

\section{a. Semantik}

Dalam hal ini, unsur semantik akan ditelaah secara gramatikal dengan melihat makna setiap klausa terlebih dahulu kemudian baru dicari makna utuh dari keseluruhan kalimat pada jargon di atas. Klausa 'bagi anda yang benci diri anda' bermakna si penulis jargon ataupun dalam hal ini si Nurhadi-Aldo bermaksud menyampaikan kepada seseorang namun tidak secara spesifik, yaitu orangorang yang merasa membenci dirinya sendiri. Klausa kedua 'ingat anda tidak sendiri', Nurhadi-Aldo mengingatkan bagi orang-orang yang membenci dirinya bahwa mereka tidak sendiri dalam membenci dirinya, tetapi masih ada orang lain yang turut membeci diri mereka. Klausa ketiga 'karena banyak yang membenci anda juga', bermakna bahwa ada orang lain yang juga membenci, tidak hanya sendiri.

Makna dari keseluruhan jargon di atas ialah, bagi seseorang yang merasa benci dengan dirinya sendiri, Nurhadi-Aldo mengingatkan bahwa ada juga orang lain yang turut membenci dirinya, tidak hanya dia sendiri.

\section{b. Stilistika}

Stilistika atau gaya bahasa yang digunakan pada jargon kali ini adalah gaya bahasa formal, serius tetapi menyampaikan sesuatu yang bersifat lawakan atau tidak terpikirkan sebelumnya. Pada umumnya, jargon bersifat himbauan ataupun doktrin-doktrin tertentu dengan tujuan tertentu juga, misalnya propaganda. Namun, kali ini pasangan Nurhadi-Aldo membuat jargon dengan gaya yang umum tetapi mengandung isi yang sebaliknya, yaitu untuk tujuan menghibur dan ringan.

\section{c. Retoris}

Retoris atau gaya interaksi yang dikesankan pada jargon ini adalah seperti sebuah himbauan yang disampaikan oleh seorang yang berwenang ataupun tokoh masyarakat, serius dan formal. Tetapi, pada kenyataannya pasangan NurhadiAldo ini hanyalah fiktif yang sengaja diciptakan dan dimunculkan di tengah suasana politik pra-Pemilu yang semakin panas. 


\section{Suntingan Gambar 2}

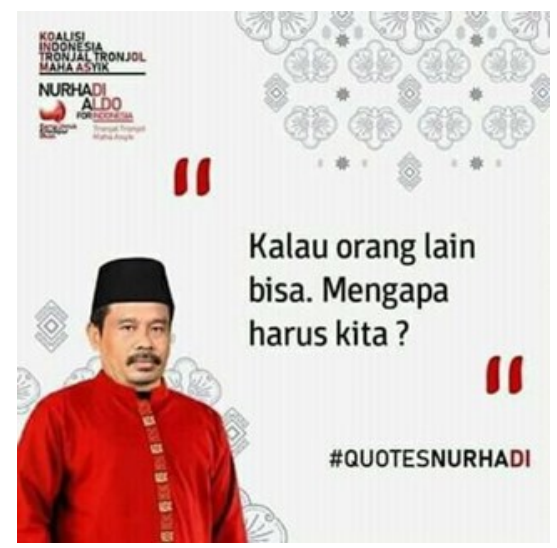

Gambar 2: gambar neologisme (meme) dengan jargon milik pasangan

Capres-Cawapres fiktif Nurhadi-Aldo.

Suntingan Teks 1: "Kalau orang lain bisa, mengapa harus kita?"

\section{Struktur Makro}

Struktur makro pada ranah pengamatan tematik pada jargon kedua ini sama seperti sebelumnya, yaitu masuk ke dalam (1) tema sosial dan (2) tema egoik. Tema sosial dapat dilihat pada frasa 'orang lain' dan kata 'kita' dimana frasa dan kata tersebut memiliki makna dua buah kelompok orang, yaitu orang lain dan kita. Tema sosial adalah hal-hal yang melibatkan antara individu dan kelompokkelompok orang atau individu lainnya. Tema egoik dapat dilihat pada maksud kalimat yang seolah-olah menyerahkan tanggung jawab kepada orang lain. Kali ini tema utama pada jargon di atas adalah tema egoik, karena keseluruhan makna dan kesan yang ditampilkan oleh jargon ini adalah egoisme atau penolakan atas sesuatu.

\section{Superstruktur}

Superstruktur dalam ranah pengamatan skematik pada jargon ini masuk ke dalam skema peran (role schemas). Skema peran berhubungan dengan cara seseorang memandang dan menggambarkan peranan dan posisi yang ditempati seseorang dalam masyarakat. Jargon ini menggambarkan bagaimana yang dimaksud 'kita' adalah sekelompok orang yang menolak diberi suatu tanggung jawab.

\section{Struktur Mikro}

\section{a. Semantik}

Klausa pertama pada jargon kedua ini ialah 'kalau orang lain bisa'. Klausa tersebut merupakan sebuah bentuk klausa terikat yang berarti pada strukturnya klausa tersebut mengandung subjek dan juga predikat tetapi belum bisa menjadi kalimat yang mandiri. Klausa 'kalau orang lain bisa' memiliki makna bahwa pasangan Nurhadi-Aldo ini menunjuk orang-orang yang sama-sama memiliki kemampuan atau kebisaan selain diri mereka. Selanjutnya klausa kedua yaitu 'mengapa harus kita?'. Klausa kedua berbentuk tanya. Sebelumnya, perlu diketahui bahwa dalam Bahasa Indonesia, kata 'kita' dan 'kami' memiliki makna 
Vol. 3, No. 2, Juli 2019, 97

Available Online at https://ejournal.warmadewa.ac.id/index.php/kulturistik DOI: dx.doi.org/10.22225/kulturistik.3.2.1221

yang berbeda dalam penggunaannya. Kata 'kita' dalam fungsinya berarti melibatkan lawan bicara dalam suatu kejadian, misalkan pada kalimat 'Kita seharusnya membantu ibu-ibu yang kecelakaan di jalan tadi.' dalam kalimat tersebut artinya si pembicara dan yang diajak bicara sama-sama harus membantu ibu-ibu yang dimaksud. Berbeda halnya dengan kata 'kami'. 'Kami' secara fungsi berarti orang yang diajak berbicara tidak terlibat dalam suatu kejadian, misalkan pada kalimat 'Kami hari ini akan menghadiri pertemuan di taman kota.' Dalam kalimat tersebut orang yang diajak bicara atau yang diberi informasi tidak ikut datang ke taman kota untuk menghadiri pertemuan, hanya dia yag berbicara dan kelompoknya. Kembali pada klausa kedua yaitu 'kenapa harus kita?' penulis meragukan maksud dari kalimat tersebut dengan menggunakan kata 'kita' di dalamnya. Secara konteks seharusnya digunakan kata 'kami' yang berarti mewakili pasangan Nurhadi-Aldo. Apabila demikian, maka klausa kedua bermakna bahwa mereka (Nurhadi-Aldo), dan pembaca jargon tersebut terlibat di dalamnya, lalu siapakah yang dimaksud dengan 'orang lain'?

Secara pemilihan kata dalam jargon tersebut mungkin keliru, namun dalam konteks keseharian jargon tersebut dapat diterima sebagai sesuatu yang menghibur. Umumnya jargon serupa berbunyi 'Kalau orang lain bisa, kenapa kami tidak?' namun bagi pasangan Nurhadi-Aldo, jargon tersebut di produksi ulang dengan memainkan kata sehingga merubah maknnya menjadi lucu dan aneh, seolah-olah tidak ingin diberikan tanggung jawab.

\section{b. Stilistika}

Seperti jargon pertama sebelumnya, stilistika yang digunakan pada jargon kali ini juga terkesan serius dan formal. Penggunaan kata 'mengapa' lebih dipilih daripada 'kenapa' menunjukkan bahwa jargon ini sengaja dibuat dengan nuansa yang serius dan formal tetapi bermakna sebaliknya yaitu lucu dan konyol.

\section{c. Retoris}

Retoris atau gaya interaksi yang dimunculkan pada jargon kedua ini adalah seperti sebuah kalimat motivasi. Tetapi di balik itu semua, jargon tersebut justru menimbulkan kesan penolakan terhadap sesuatu. Kesan yang dibangun melalui permainan kata-kata ini cukup berhasil menyampaikan nilai humor yang khas. Tujuan dari diciptakannya jargon ini juga tersampaikan dengan baik karena tidak umum atau jarang terpikirkan oleh orang lain. Sebuah kalimat motivasi dapat diubah susunannya menjadi kalimat yang menunjukkan penolakan, keengganan atau sikap apatis.

\section{SIMPULAN}

Penelitian ini membahas tetang fenomena kemunculan pasangan CapresCawapres fiktif Nurhadi-Aldo di tengah-tengah panasnya situasi perpolitikan Indonesia pra-Pemilu 2019. Keunikan jargon dari hasil permainan kata-kata yang digunakan menarik untuk dibahas secara makna dan struktur kalimatnya. Dalam menemukan makna dalam teks jargon-jargon Nurhadi-Aldo ini, digunakan sebuah teori analisis wacana dari Van Dijk dengan cara membagi sebuah teks ke dalam tiga ranah pengamatan yaitu (1) struktur makro, (2) superstrukrur, dan (3) struktur mikro dari sebuah teks.

Struktur makro berbicara tentang tematik atau tema-tema pada suatu teks dan dibagi lagi menjadi dua hal yaitu, (1) tema pokok/tema mayor dan (2) tema 
Vol. 3, No. 2, Juli 2019, 98

Available Online at https://ejournal.warmadewa.ac.id/index.php/kulturistik DOI: dx.doi.org/10.22225/kulturistik.3.2.1221

tambahan/tema minor. Pada teks jargon yang pertama yaitu "Bagi anda yang benci diri anda sendiri, ingat anda tidak sendiri, karena banyak yang membenci anda juga." mengandung dua buah tema yaitu: (1) tema sosial dan (2) tema egoik. Tema sosial ditujukkan dalam klausa 'diri anda sendiri', dan 'karena banyak yang membenci anda juga'. Hubungan sosial adalah hubungan antara pribadi dan orang lain, maka dari itu yang menjadi tema pokok dari jargon di atas adalah tema sosial. Tema minor atau tema tambahan jargon di atas adalah tema egoik. Pada klausa 'bagi anda yang benci diri anda sendiri', memiliki arti bahwa seseorang yang merasa benci terhadap dirinya sendiri, dimana perasaan tersebut merupakan bentuk ego diri yang menilai diri sendiri maupun orang lain.

Pada teks jargon yang kedua "Kalau orang lain bisa, mengapa harus kita?" juga memiliki dua buah tema yaitu: (1) tema sosial dan (2) tema egoik. Tema sosial dapat dilihat pada frasa 'orang lain' dan kata 'kita' dimana frasa dan kata tersebut memiliki makna dua buah kelompok orang, yaitu orang lain dan kita. Tema sosial adalah hal-hal yang melibatkan antara individu dan kelompok-kelompok orang atau individu lainnya. Tema egoik dapat dilihat pada maksud kalimat yang seolah-olah menyerahkan tanggung jawab kepada orang lain. Kali ini tema utama pada jargon di atas adalah tema egoik, karena keseluruhan makna dan kesan yang ditampilkan oleh jargon ini adalah egoisme atau penolakan atas sesuatu.

Selanjutnya adalah superstruktur. Superstruktur berbicara pada ranah pengamatan skematik yaitu Skema berarti alur penyajian suatu teks, yaitu bagaimana struktur dan elemen wacana itu disusun dalam teks secara utuh. Superstruktur pada jargon pertama memasukkan jargon di atas ke dalam skema persona (person schemas). Hal tersebut karena jargon tersebut berisikan hal tentang pandangan seseorang terhadap orang lain. Orang lain yang dimaksud adalah orang yang membenci dirinya sendiri seperti yang tertulis pada jargon. Superstruktur pada jargon kedua masuk ke dalam skema peran (role schemas). Skema peran berhubungan dengan cara seseorang memandang dan menggambarkan peranan dan posisi yang ditempati seseorang dalam masyarakat. Jargon ini menggambarkan bagaimana yang dimaksud 'kita' adalah sekelompok orang yang menolak diberi suatu tanggung jawab.

Kemudian adalah struktur mikro yang terdiri dari ranah pengamatan (1) semantik, (2) sintaksis, (3) stilistika, dan (4) retoris. Namun dalam penelitian ini pembahasa tentang sintaksis tidak digunakan karena tidak ada data yang dapat dikaji. Pada jargon pertama, secara semantik makna dari keseluruhan jargon tersebut ialah, bagi seseorang yang merasa benci dengan dirinya sendiri, NurhadiAldo mengingatkan bahwa ada juga orang lain yang turut membenci dirinya, tidak hanya dia sendiri. Sedangkan secara stilistika atau gaya bahasa yang digunakan pada jargon pertama adalah gaya bahasa formal dan serius tetapi menyampaikan sesuatu yang bersifat lawakan atau tidak terpikirkan sebelumnya. Secara retoris atau gaya interaksi yang dikesankan pada jargon pertama adalah seperti sebuah himbauan yang disampaikan oleh seorang yang berwenang ataupun tokoh masyarakat, serius dan formal. Tetapi, pada kenyataannya pasangan Nurhadi-Aldo ini hanyalah fiktif yang sengaja diciptakan dan dimunculkan di tengah suasana politik pra-Pemilu yang semakin panas.

Pada jargon kedua, secara semantik jargon tersebut di produksi ulang dengan memainkan kata sehingga merubah maknnya menjadi lucu dan aneh, seolah-olah tidak ingin diberikan tanggung jawab. Secara stilistika, pada jargon kedua ini juga terkesan serius dan formal. Penggunaan kata 'mengapa' lebih 


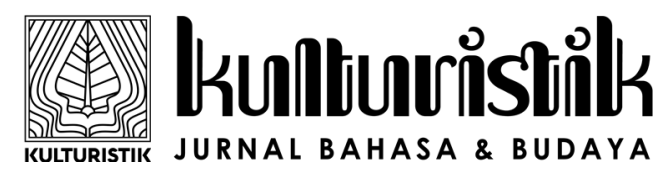

Vol. 3, No. 2, Juli 2019, 99

Available Online at https://ejournal.warmadewa.ac.id/index.php/kulturistik DOI: dx.doi.org/10.22225/kulturistik.3.2.1221

dipilih daripada 'kenapa' menunjukkan bahwa jargon ini sengaja dibuat dengan nuansa yang serius dan formal tetapi bermakna sebaliknya yaitu lucu dan konyol. Secara retoris, atau gaya interaksi yang dimunculkan pada jargon kedua ini adalah seperti sebuah kalimat motivasi. Tetapi di balik itu semua, jargon tersebut justru menimbulkan kesan penolakan terhadap sesuatu.

\section{DAFTAR PUSTAKA}

Chaer, A. (2011). Tata Bahasa Praktis Bahasa Indonesia. Jakarta: Rineka Cipta. Endarmoko. (2006). Tesaurus Bahasa Indonesia. Jakarta: PT.Gramedia.

Gorys, K. (1980). Tata Bahasa Indonesia. Jakarta: Nusantara.

Kamus Besar Bahasa Indonesia. (n.d.). Retrieved from kbbi.kemdikbud.go.id/ entri/religius

Kridalaksana, H. (2008). Kamus Linguistik. Jakarta: PT.Gramedia.

Sayuti, A. S. (2000). Berkenalan dengan Prosa Fiksi. Yogyakarta: Gama Media.

Sudaryanto. (1993). Metode dan Aneka Teknik Analisis Bahasa (Pengantar Penelitian Wahana Kebudayaan Secara Linguistis). Yogyakarta: Duta Wacana University Press. 